\title{
Adjustments in population and reproductive dynamics of native and non-native congeneric species during 26 a years after invasion
}

Correspondence:

Amanda Cantarute Rodrigues amandacantarute@gmail.com
Submitted May 20, 2020

Accepted December 12, 2020

by Elizete Rizzo

Epub 22 Feb, 2021

\section{${ }^{\oplus}$ Amanda Cantarute Rodrigues ${ }^{1},{ }^{\oplus}$ Natália Carneiro Lacerda dos Santos ${ }^{1}$, ${ }^{\oplus}$ Matheus Tenório Baumgartner ${ }^{1}$ and ${ }^{\oplus}$ Luiz Carlos Gomes ${ }^{1}$}

We aimed to improve the understanding of the establishment of Serrasalmus marginatus (non-native), which was followed by a decrease in the abundance of Serrasalmus maculatus (native) in the upper Paraná River floodplain. We estimated age, mortality rate, length and age at first maturity and variations in gonad development in three time-periods along a 26-year truncated time scale for both species. Population and reproduction parameters of both species showed substantial fluctuations among periods. Most age classes were sampled in all timeperiods, but with considerable difference in abundance, with predominance of older individuals in the second time-period and younger individuals in the third time-period for both species. The mortality rates decreased for both species in the second time-period, but increased for the native in the third time-period. Length and age at first maturity decreased in the second time-period for both species, increasing the number of mature individuals on their populations. In the third time-period, the number of immature individuals increased for both species. We suggest that species experienced stressful conditions during cooccurrence and this have resulted in physiological responses in both species, reflecting in population and reproductive adjustments that may have relaxed competitive interactions between them, optimizing survival, reproductive effort and coexistence.

Keywords: Age structure, Biological invasions, Length at first maturity, Mortality, Serrasalmus.
Online version ISSN 1982-0224 Print version ISSN 1679-6225

Neotrop. Ichthyol. vol. 19, no. 1, Maringá 2021

\footnotetext{
1 Programa de Pós-Graduação em Ecologia de Ambientes Aquáticos Continentais, Universidade Estadual de Maringá, Av. Colombo, 5790, 87020-900 Maringá, PR, Brazil. (ACR) amandacantarute@gmail.com (corresponding author), (NCLS) natalia.ictio@gmail.com, (MTB) matheus_tbs@hotmail.com, (LCG) lcgomes@nupelia.uem.br.
} 
Nosso objetivo foi aumentar o conhecimento sobre o estabelecimento de Serrasalmus marginatus (não nativa), que foi seguido pela diminuição na abundância de Serrasalmus maculatus (nativa) na planície de inundação do alto rio Paraná. Estimamos a idade, taxa de mortalidade, comprimento e idade de primeira maturação e variações no desenvolvimento gonadal em três períodos ao longo de 26 anos para as espécies. Os parâmetros populacionais e de reprodução das espécies mostraram flutuações substanciais. A maioria das faixas etárias foi amostrada em todos os períodos, mas com diferenças consideráveis na abundância, predominando indivíduos mais velhos no segundo período e indivíduos mais jovens no terceiro período para ambas as espécies. A taxa de mortalidade diminuiu para as espécies no segundo período, mas aumentou para a espécie nativa no terceiro período. O comprimento e a idade de primeira maturação diminuíram no segundo período para as espécies, aumentando o número de indivíduos adultos. No terceiro período, o número de indivíduos imaturos aumentou para ambas as espécies. Sugerimos que as espécies passaram por condições estressantes durante a coocorrência, resultando em respostas fisiológicas que desencadearam ajustes populacionais e reprodutivos que podem ter minimizado a interação competitiva entre elas, otimizando a sobrevivência, o esforço reprodutivo e a coexistência.

Palavras-chave: Comprimento de primeira maturação, Estrutura etária, Invasões biológicas, Mortalidade, Serrasalmus.

\section{INTRODUCTION}

Invasive species in aquatic communities can cause several impacts at population level (Cucherousset, Olden, 2011). Two known impacts are demographic and distributional effects, affecting the size of the population (e.g., abundance) and displacing the native population from optimal habitats through competitive exclusion. These would occur because of a possible competition between native and non-native populations, which may eventually compete directly for food and space (Shelton et al., 2008; Saylor et al., 2012; Jermacz et al., 2015; Jůza et al., 2018). Competitive interactions can severely affect native populations, determining growth and mortality (Ross, 1991; Sparre, Venema, 1992; Gomiero et al., 2010), leading to local extinctions in some cases (MacNeil et al., 2004; Bøhn et al., 2008; Ellender et al., 2011). To avoid this negative effect, it may be expected that species present adjustments in population dynamics for mutual survival between competitors, aiming to optimize survival and reproductive effort (RamírezGarcía et al., 2018).

In cases when a non-native species is phylogenetically related to a native one, the competition between them is increased, since they usually share similar resources and have similar life-strategies (Gois et al., 2015; Rodrigues et al., 2018). This is the case of Serrasalmus marginatus Valenciennes, 1837, a congener piranha of the native Serrasalmus maculatus Kner, 1858 (named Serrasalmus spilopleura Kner, 1858 until the differentiation by Jégu, dos Santos, 2001) in the upper Paraná River floodplain. These two species came up to coexist in the floodplain after the filling of the Itaipu 
Reservoir in 1982 and the consequently submersion of a natural geographic barrier, which led to the invasion of several fish species at the upper portion of the Paraná River (Júlio Junior et al., 2009; Vitule et al., 2012). Few years after the introduction, the non-native already dominated quantitatively over its native congener, dispersing all over the floodplain (Agostinho, Júlio Jr., 2002; Agostinho, 2003; Rodrigues et al., 2018). In turn, the population of S. maculatus decreased drastically, suggesting its exclusion from specific habitats (Agostinho, Júlio Jr., 2002; Agostinho, 2003). Some authors suggested competition between species, for food, since they share the same trophic niche (Agostinho et al., 2003) and for breeding sites, since both species live and reproduce preferably in lentic environments (Agostinho, Júlio Jr., 2002; Agostinho, 2003). Indeed, Alexandre et al. (2004) evaluated the stock-recruitment relationship of both species and concluded that competition was one of the determinant mechanisms of the recruitment of piranhas, especially for breeding sites. Recent studies showed that both species still coexist in the floodplain, although with different main energy sources (Alves et al., 2017), different spatial distribution patterns (Rodrigues et al., 2018) and in different proportions, as suggested by Agostinho, Júlio Jr. (2002). Rodrigues et al. (2018) evaluated the spatial patterns of both species and found that when species presented high abundances they were spatially aggregated, cooccurring in the same habitat. This was mainly observed when the non-native species had a fast abundance increase, which was followed by a decrease in the abundance of the native species. Although competition itself is difficult to quantify in mobile organisms such as fish, this is a strong empirical evidence of potential competitive pressure of the non-native piranha over the native, especially considering the small-scale habitat selection (see Rodrigues et al., 2018 for more details).

In this study, we intended to expand the knowledge on the establishment of $S$. marginatus (non-native), which was suggested to strongly affect the population of $S$. maculatus (native). For this, our goals were 1) to evaluate how the abundance of nonnative and native species is related to spatial and temporal factors and the abundance of its congeneric species and 2) to compare population attributes (size of population, age structure, mortality rate, and age at first maturation) and the reproduction cycle of species. For that end, we analyzed data collected in three time-periods over a 26 -year truncated time scale, to seek for evidence that might explain the observed population shifts and adjustments on both non-native and native species. Considering that species sharing similar ecological requirements may show increased competition between themselves and non-native species may impact native species in several ways (as above mentioned) we hypothesize that the cooccurrence between both piranhas reflected in shifts in population and reproduction attributes of both species over time. Precisely, the cooccurrence reflected in i) alterations of abundance, decreasing the abundance of the native species, which would led to a truncated age structure of the native population; ii) variations in mortality rates, increasing the rates for both species in periods of high abundance of them and iii) changes in age at first maturation for both species, becoming earlier due to competition. It is important to mention that our data comprehends only information about post-invasion event, therefore our focus is to understand how species behave when cooccurring together over time. 


\section{MATERIAL AND METHODS}

Study area. The upper Paraná River floodplain is located between the Porto Primavera Dam (North) and the Itaipu Reservoir (South) and represents the last undammed stretch $(230 \mathrm{~km}$ long) of the Paraná River within the Brazilian territory (Agostinho et al., 2015). This floodplain exhibits an intricate anastomosis involving secondary channels, floodplain lakes, the Baía River and the lower curses of the right-margin rivers, such as the Ivinheima River (Fig. 1; Agostinho, Zalewski, 1996; Agostinho et al., 2008). Until the construction of the Itaipu Dam, upper and middle parts of the Paraná River were separated by the Sete Quedas Falls, a 114-meters high natural geographic barrier that is now submerged in the upper part of this reservoir (Agostinho, Zalewski, 1996). The submersion of the falls allowed the invasion of several species of the middle part to the upper part of the Paraná River, including the piranha S. marginatus (Júlio Junior et al., 2009).

Samplings. Abundance data of $S$. marginatus and S. maculatus were obtained from different studies conducted by the Núcleo de Pesquisas em Limnologia, Ictiologia e Aquicultura (Nupélia) from the Universidade Estadual de Maringá (UEM), Brazil. These studies encompassed 26 years: from October 1986 to September 1988 with monthly samplings (herein named first time-period), February 2000 to November 2002 with quarterly samplings (second time-period), and from March 2010 to December 2012 also with

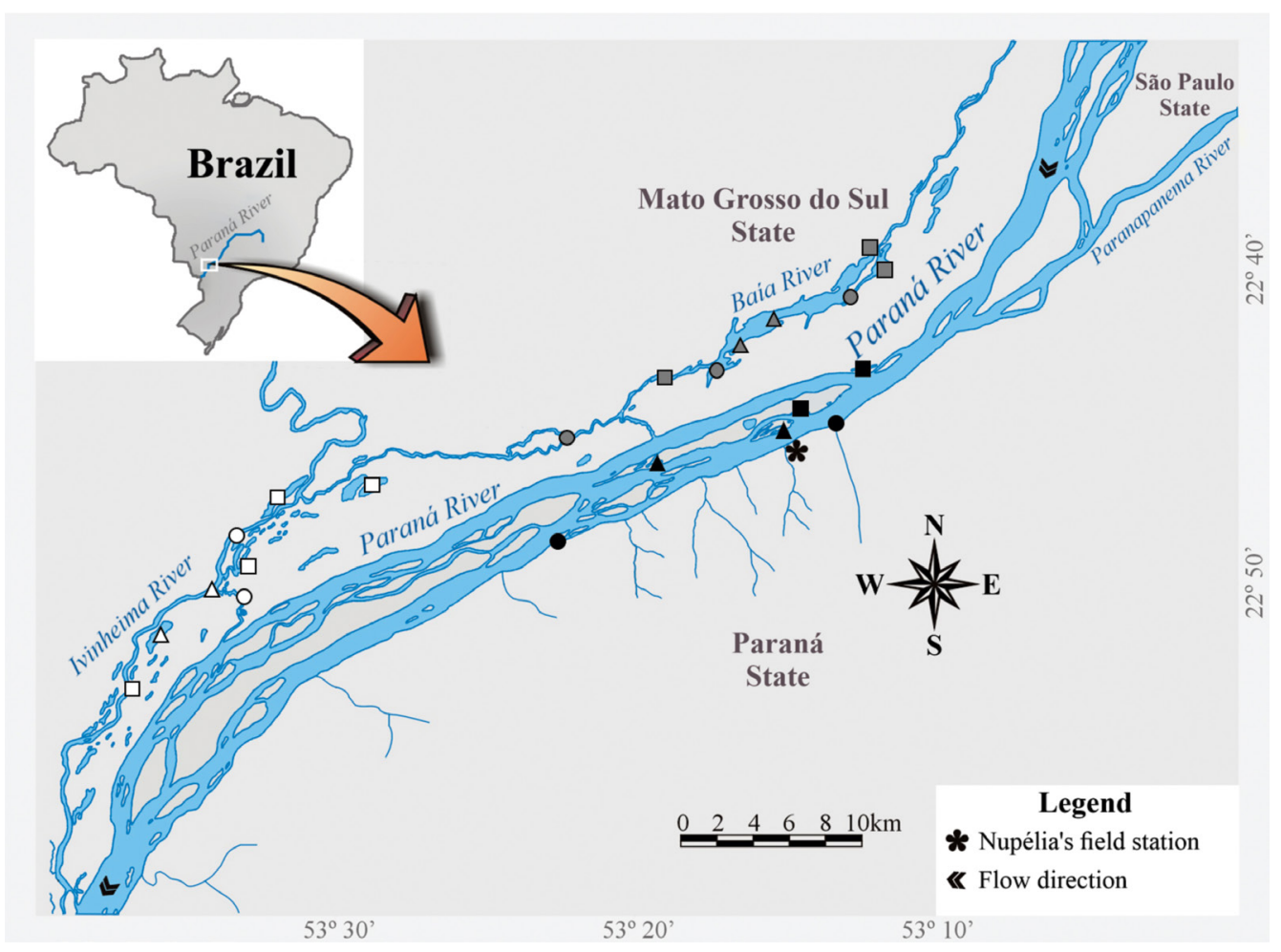

FIGURE 1 I Map of the upper Paraná River floodplain showing its main tributaries. Sampling sites are marked: rivers and channels (circles), connected (squares), and isolated (triangles) floodplain lakes. Color of symbols are for Paraná (black), Ivinheima (white), and Baía (grey) rivers. 
quarterly samplings (third time-period). Voucher specimens are hosted in the Coleção Ictiológica of the Nupélia, under numbers NUP 439 for S. marginatus and NUP 396 for S. maculatus. A total of 22 sites were sampled in the upper Paraná River floodplain (Fig. 1), including lotic environments (rivers and secondary channels), connected and isolated floodplain lakes.

All fish samplings were conducted using gillnets of different mesh sizes $(24 ; 30 ; 40$; 50; 60; 70; 80; 100; 120; 140 and $160 \mathrm{~mm}$ between opposite knots; $24 \mathrm{~mm}$ mesh used only after 2000), set at each sampling site for $24 \mathrm{~h}$ (checked every eight hours). All individuals sampled were anaesthetized with $5 \%$ benzocaine and killed (Resolução $\mathrm{n}^{0}$ 1000/12, Conselho Federal de Medicina Veterinária). The sampling process was followed by species identification, measurement of total and standard length ( $\mathrm{mm}$ ), weighting $(\mathrm{g})$ and analysis of gonads for sex and maturation stages records according to Brown-Peterson et al. (2011).

Data analysis. Abundance data of $S$. marginatus and $S$. maculatus were indexed according to the capture per unit effort (CPUE; number of individuals/1000 $\mathrm{m}^{2}$ of gillnets in $24 \mathrm{~h}$ ) in each sample (month and site of sampling). We performed linear models using the abundance of each species as response variables to evaluate how the abundance of species is related to (i) the system, using River as variable (Baía, Ivinheima and Paraná), (ii) the habitats (secondary channels, connected and isolated floodplain lakes and river), (iii) the temporal scale and (iv) the abundance of the congeneric species. We decided to consider the spatial variation of the floodplain since Serrasalmus species shows habitat preferences and this may reflect in significant shifts in the abundance of species between sites. The congeneric species were considered in order to evaluate if its abundance explained part of the variation of the response variable. The abundance variables of both species were $\log (x+1)$ transformed. For linear models, we used $\eta^{2}$ (eta squared) to describe the proportion of total variation attributable to the different sources of variation. All analyses were performed with the $\mathrm{R}$ environment software $(\mathrm{R}$ Development Core Team, 2017).

Our second goal was to analyze the population and reproduction patterns of both species over time. For this, we did not considered the different spatial samples in the following analyses. Therefore, the analyses were performed considering only a truncated time scale (three discrete sample periods), in which we evaluated population and reproduction attributes of both species. Population attributes estimated were age and mortality rates of species, and reproduction parameters estimated were age and length at first maturity and maturation stages.

Age was estimated using the inverted von Bertalanffy growth function on individual total length as described by Gulland (1969). However, we chose to replace total length by standard length (SL), since several fish did not have their caudal fin intact. The modified equation is given by:

$$
t=\frac{1}{k} \log _{e} \frac{L \infty}{L \infty-L S}+t_{0}
$$

where $t$ is the individual age, $\mathrm{k}$ is the body growth coefficient, $\mathrm{L} \infty$ is the theoretical asymptotic standard length, Ls is the standard length at age $t$, and $t_{0}$ is the theoretical 
age when fish length equals 0 . The growth parameters employed were those from Agostinho, Marques (1994) for both Serrasalmus species in the upper Paraná River floodplain, estimated through readings of annual rings in vertebrae for separate sexes, since females reach larger body sizes (Tab. 1 ).

Age frequency analyses were performed to identify alterations in age classes of both species. In Agostinho, Marques (1994), the maximum age reported was eight years for both species, but in our work we considered more two years due to the considerable values of observed abundances of older individuals.

Estimates of total mortality $(Z)$ were obtained using the linearized catch curve method described by Miranda, Bettoli (2007). Curves were estimated from speciesspecific and period-specific age structures through linear regressions, plotting the natural logarithm of the number of individuals in each age class against their corresponding age. The regression fit were made according to Ricker (1975), using only the data at the descending part of the catch curves, once the ascendant part represents age classes that are inferior to initial recruitment and are not fully captured. $\mathrm{Z}$ was estimated as the absolute slope of the fitted line. The estimates of $\mathrm{Z}$ were obtained with the R environment software (R Development Core Team, 2017) and the catch curve was plotted using the "catchCurve" function from the "FSA" package (Ogle, 2017).

Additionally, estimates of the mean age at first maturity $\left(\mathrm{A}_{50}\right)$ and the mean length at first maturity $\left(\mathrm{L}_{50}\right)$ were obtained by fitting logistic regression models. For each combination of sex and time period for both species, a single logistic regression model was applied with the natural logarithm of the odds of an individual being mature (i.e., logit link), as a linear function of the explanatory variable (age and standard length), where maturity was assumed to follow a Bernoulli distribution (Yates et al., 2018). Nonparametric bootstraps with 10,000 iterations were used to calculate confidence intervals (C.I.). The estimates were made with the $\mathrm{R}$ environment software using function "lencat" of the "FSA" package.

The frequency of maturation stages was estimated at each age for both species. Following the gonadal classification of Brown-Peterson et al. (2011), maturation stages were assigned as follow: Immature (never spawned), Developing (gonads beginning to grow and develop), Spawning capable (fish are developmentally and physiologically able to spawn in this cycle), Regressing (cessation of spawning) and Regenerating (sexually mature, reproductively inactive).

TABLE 1 I Growth parameters estimated by Agostinho, Marques (1994) for both sexes of Serrasalmus marginatus and $S$. maculatus in the upper Paraná River floodplain. Lo: theoretical asymptotic standard length; $\mathrm{k}$ : body growth coefficient; $\mathrm{t}_{\mathrm{o}}$ : theoretical age when fish length equals 0 .

\begin{tabular}{|c|c|c|c|c|}
\hline & & \multicolumn{3}{|c|}{ Parameters } \\
\hline & & $\mathrm{L} \infty(\mathrm{cm})$ & $\mathrm{K}\left(\right.$ year $\left.^{-1}\right)$ & $t_{0}$ \\
\hline \multirow{2}{*}{$\begin{array}{c}\text { Serrasalmus marginatus } \\
\text { (non-native) }\end{array}$} & Male & 19.03 & 0.253 & -0.538 \\
\hline & Female & 22.11 & 0.191 & -0.789 \\
\hline \multirow{2}{*}{ Serrasalmus maculatus (native) } & Male & 24.98 & 0.208 & -1.064 \\
\hline & Female & 28.30 & 0.174 & -1.043 \\
\hline
\end{tabular}




\section{RESULTS}

The total CPUE sampled varied greatly over time-periods for both species. For $S$. marginatus, total CPUE values were 4395 in the first time-period, 13337 in the second time-period and 28576 in the third time-period. For S. maculatus, the total CPUE values were very different: 9939 in the first time-period, 802 in the second time-period and 2503 in the third time-period. Fig. 2 represents the temporal trends in abundance of each species in each habitat. The first noticeable thing is the inversion of the dominance between the piranha species. The first time-period was dominated in abundance by the native species, but it decreased and became less abundant in second and third periods. Meanwhile, the non-native $S$. marginatus greatly increased in CPUE over time, becoming almost 11 times more abundant in the floodplain when compared to the native piranha species. According to the results of the linear model, these variations in the abundance of both species occurred according to the rivers of the floodplain, the type of habitat, the years and the CPUE of the respective congeneric species (Tab. 2). Besides, for both species, the Year variable explained the largest proportion of variation.
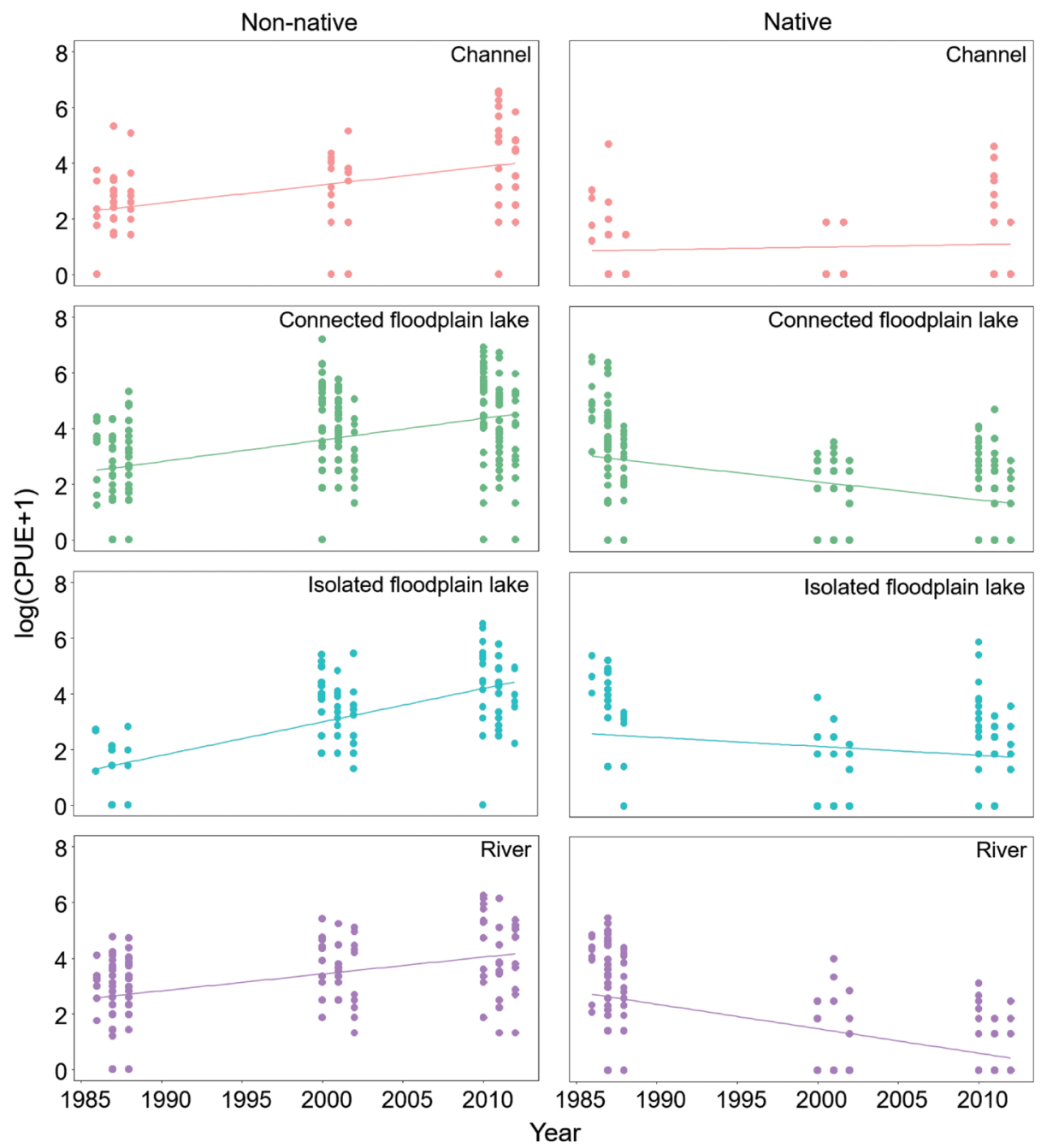

FIGURE 2 I Temporal trends in abundance of both non-native (left) and native species (right) in each habitat. CPUE values were $\log (\mathrm{x}+1)$ transformed to decrease extreme values. 
TABLE 2 I Results of linear models of the abundance of the two species with rivers, habitats, year and the CPUE of the congeneric species. $\eta^{2}=$ proportion of variation explained (eta squared); $S S=$ sum of squares; d.f. = degrees of freedom. $\mathrm{p}$ values $<0.05$ are in bold.

\begin{tabular}{|c|c|c|c|c|c|c|}
\hline $\begin{array}{l}\text { Dependent } \\
\text { variable ( }{ }^{2} \\
\text { adj) }\end{array}$ & Source of variation & $\eta^{2}$ & SS & d.f. & $\mathbf{F}$ & $\mathbf{p}$ \\
\hline \multirow{5}{*}{ 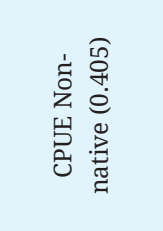 } & River & 0.079334 & 21.875 & 2 & 37.6483 & $<0.001$ \\
\hline & Habitat & 0.025988 & 7.166 & 3 & 8.2219 & $<0.001$ \\
\hline & Year & 0.270676 & 74.634 & 1 & 256.9015 & $<0.001$ \\
\hline & CPUE Native & 0.048725 & 13.435 & 1 & 46.2458 & $<0.001$ \\
\hline & Residuals & & 158.621 & 546 & & \\
\hline \multirow{5}{*}{ 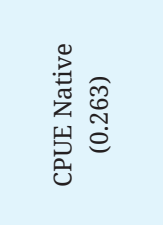 } & River & 0.029888 & 8.489 & 2 & 11.379 & $<0.001$ \\
\hline & Habitat & 0.075329 & 21.396 & 3 & 19.119 & $<0.001$ \\
\hline & Year & 0.116979 & 33.227 & 1 & 89.072 & $<0.001$ \\
\hline & CPUE Non-native & 0.060735 & 17.251 & 1 & 46.246 & $<0.001$ \\
\hline & Residuals & & 203.676 & 546 & & \\
\hline
\end{tabular}

Along with the fluctuation in the population size, there was also remarkably variations in the frequency of individuals within each age classes among time-periods (Fig. 3). Both species presented higher frequencies of older individuals in the second time-period when compared to the first one (highest upper quartiles; Fig. 4). But it also changed in the third time-period, when both species showed an increase in the frequency of younger individuals, leading to a decrease in the most frequent age sampled for both species (from age 5 to 3 for the non-native species and from age 4 to 3 for the native species; Fig. 4).

The mortality rates $(\mathrm{Z})$ also showed great variations among time-periods for both species (Fig. 5). Mortality was estimated from fully recruited ages: 5, 6 and 3 for the non-native species in the first, second and third time-period, respectively and 4, 5 and 4 for the native species in the first, second and third time-period, respectively. Between first and second time-periods, the variation was more evident, decreasing mortality for both species (the slope of the curve is lower). However, while for the non-native species mortality continued to decrease in the third time-period, for the native species it has increased (the slope of the curve is higher), resembling the pattern observed in the first time-period of sampling.

There were relevant variations in the reproductive maturation stages through timeperiods. Overall, the proportion of mature individuals (stages Developing, Spawning capable, Regressing and Regenerating) increased from the first to the second timeperiod, but decreased in the third time-period for both species, always with the nonnative presenting more immature individuals (Tab. 3, Fig. 6). Accordingly, for both species, the number of immature individuals increased in the third time-period (Tab. 3). For the non-native species, the number of immature individuals was substantially higher compared to the first years of sampling, revealing a remarkable population increase for this species. However, for the native species, the number of immature individuals was similar to that found in the first time-period, even though the number of total individuals is lower. 


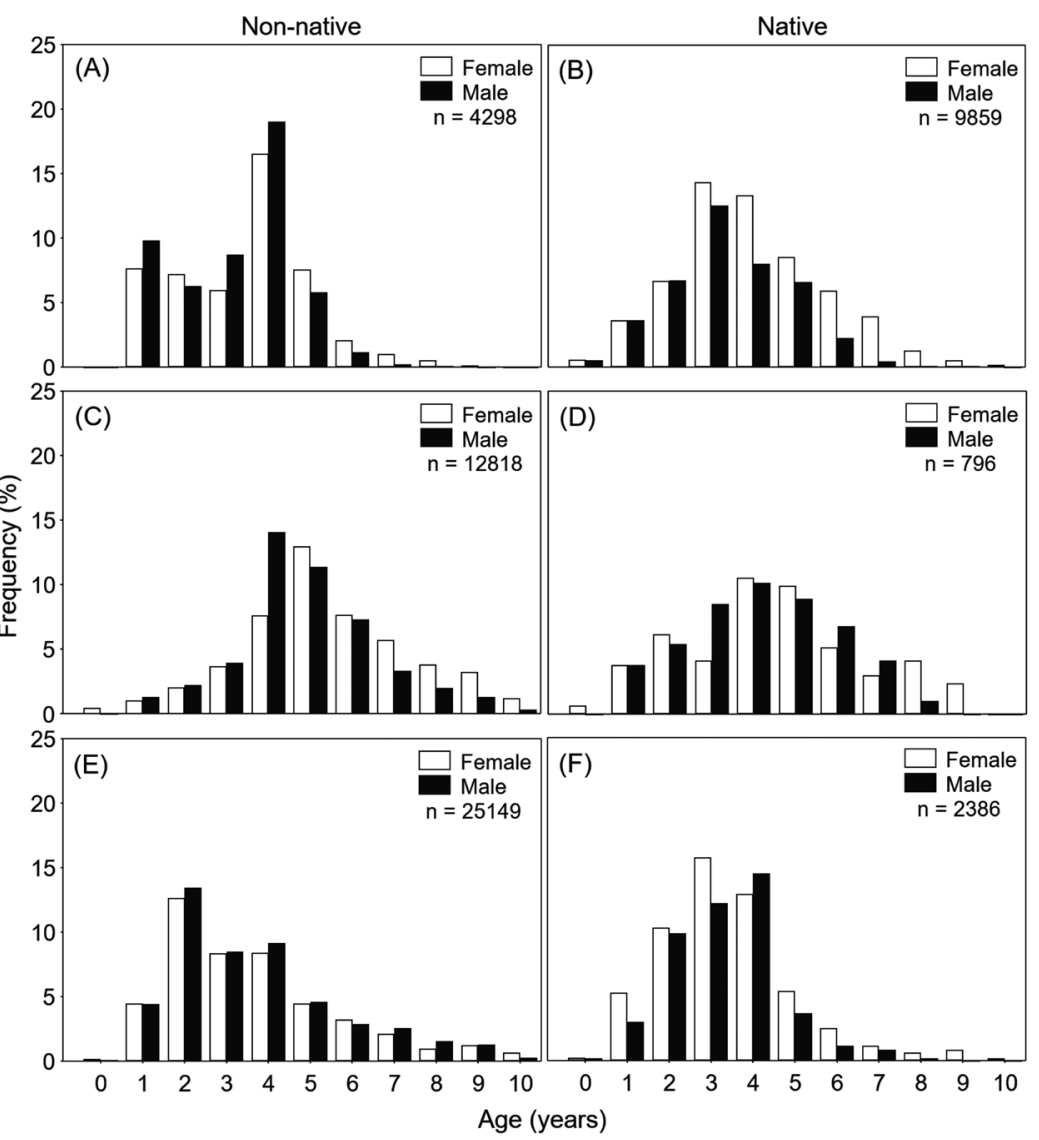

FIGURE 3 । Age frequencies of both non-native (left) and native species (right) for each sex and each sampled time-period in the upper Paraná River floodplain. A. and B. 1986-1988: first time-period; C. and D. 2000-2002: second time-period; E. and F. 2010-2012: third time-period. CPUE values are fewer when compared to total CPUE values since individuals without standard length and sex were not considered in the estimation of age.

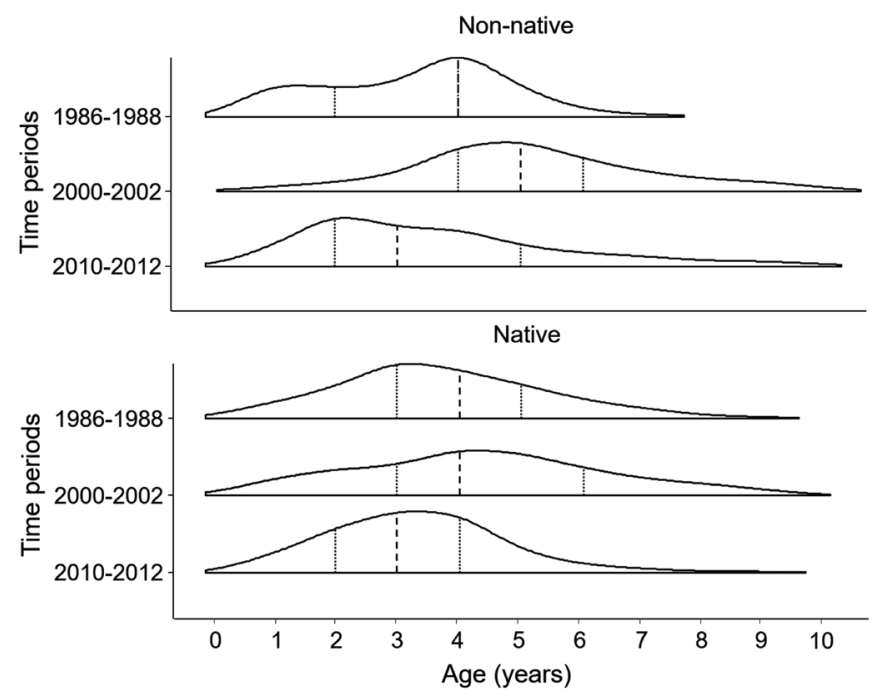

FIGURE 4 I Frequency distribution of age classes by time-period of both non-native and native species in the upper Paraná River floodplain. Dashed line: median; dotted line: lower and upper quartiles. 
Non-native
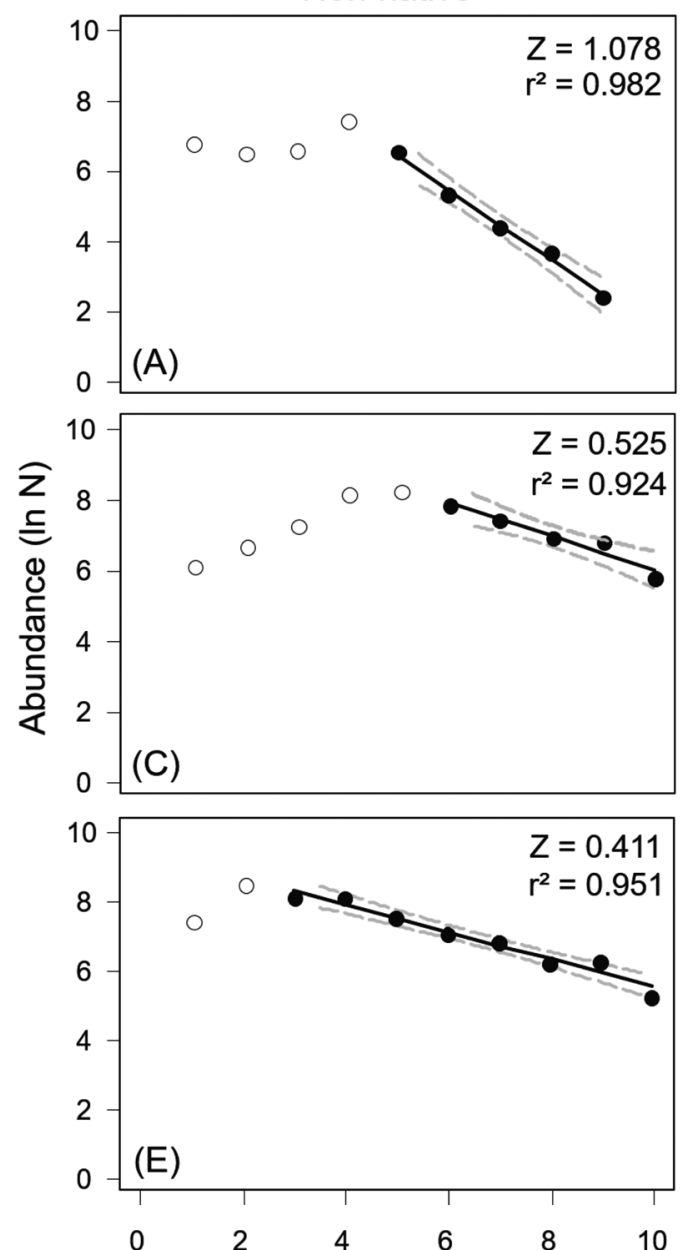

Native
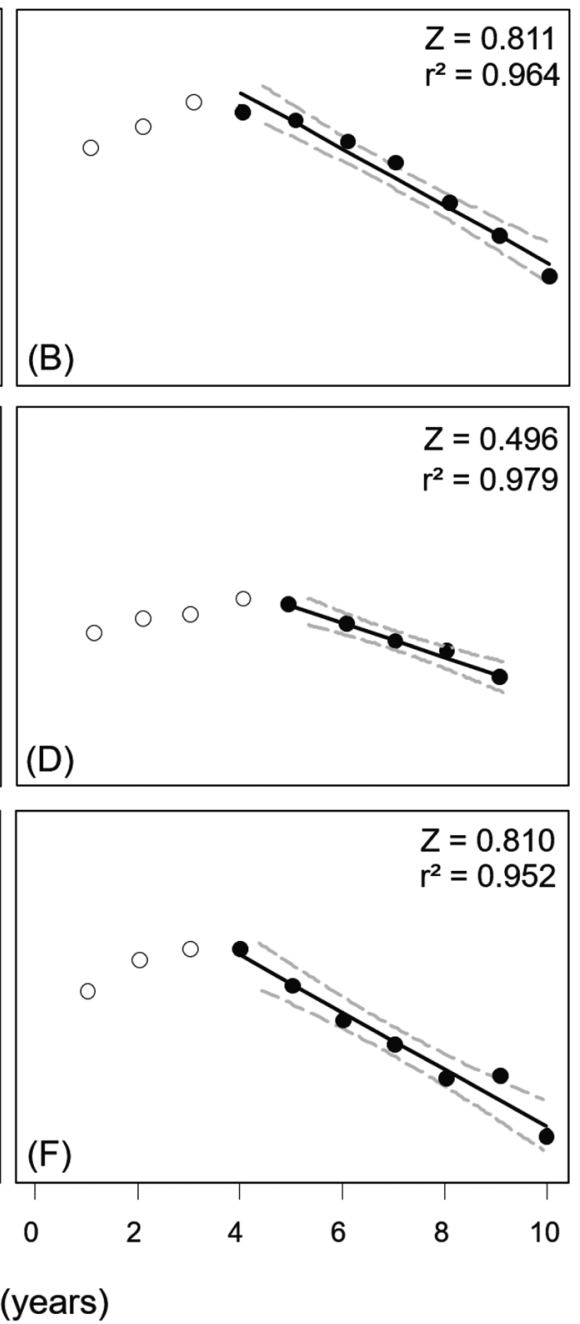

FIGURE 5 I Mortality rates of both non-native (left) and native (right) species for each sampled timeperiod in the upper Paraná River floodplain. White dots: ages that were not used for the estimated mortality. Black dots: ages used for the estimated mortality. Grey dashed line: confidence intervals. A. and B. 1986-1988: first time-period; C. and D. 2000-2002: second time-period; E. and F. 2010-2012: third time-period.

This pattern was consistent with the variations in the mean age and length at first maturity (Tab. 4, Fig. 7). The estimated models showed that both mean age and length at first maturity decreased in the second time-period (individuals were maturing earlier and smaller, increasing the proportion of mature individuals in the population) and increased in the third time-period. However, for both species, the highest estimated $\mathrm{A}_{50}$ and $\mathrm{L}_{50}$ were observed in the third time-period, with individuals maturing larger and older. 
TABLE 3 I Number of Serrasalmus marginatus (non-native) and S. maculatus (native) analyzed to identify gonad development by sex and time-period in the upper Paraná River floodplain.

\begin{tabular}{|c|c|c|c|c|c|}
\hline \multirow{2}{*}{ Time-period } & \multirow{2}{*}{ Sex } & \multicolumn{3}{|c|}{ Number of fish } & Proportion of \\
mature
\end{tabular}

\section{DISCUSSION}

The population and reproductive attributes of Serrasalmus marginatus (non-native) and S. maculatus (native) showed substantial variations in the studied time-periods. These variations seem to follow the same pattern for both species, suggesting that they may have been submitted to similar biotic and abiotic stressful conditions, reflecting in physiological responses that would enable their coexistence. Overall, when comparing both species, the non-native apparently showed an advantage over the native species in few years after the introduction, especially regarding population size and reproductive capacity, which strongly suggests a reproductive success greater than the native species.

Considering the time-periods studied, the most pronounced shifts arose from abundances and the variation in age and length at first maturity for both species. In relation to the first one, the linear models indicated all predictors as significant drivers. In line with several previous studies (e.g., Ortega et al., 2018), we also report low amount of explanation of all predictors, as it is recurrent in ecological data of many studies but it is still possible to suggest patterns. We found that both species abundances had the years as the most important source of variation, indicating that both species had considerable variations along time. According to Hardin (1960), competition between two formerly separated species may be suggested if there is a reduction in density or the extinction of one of the two populations in the environment. For fish, evidences of competition were already demonstrated in some cases, as in Bøhn et al. (2008), Gois et al. (2015) and Jůza et al. (2018). From the case of the piranhas in the upper Paraná 


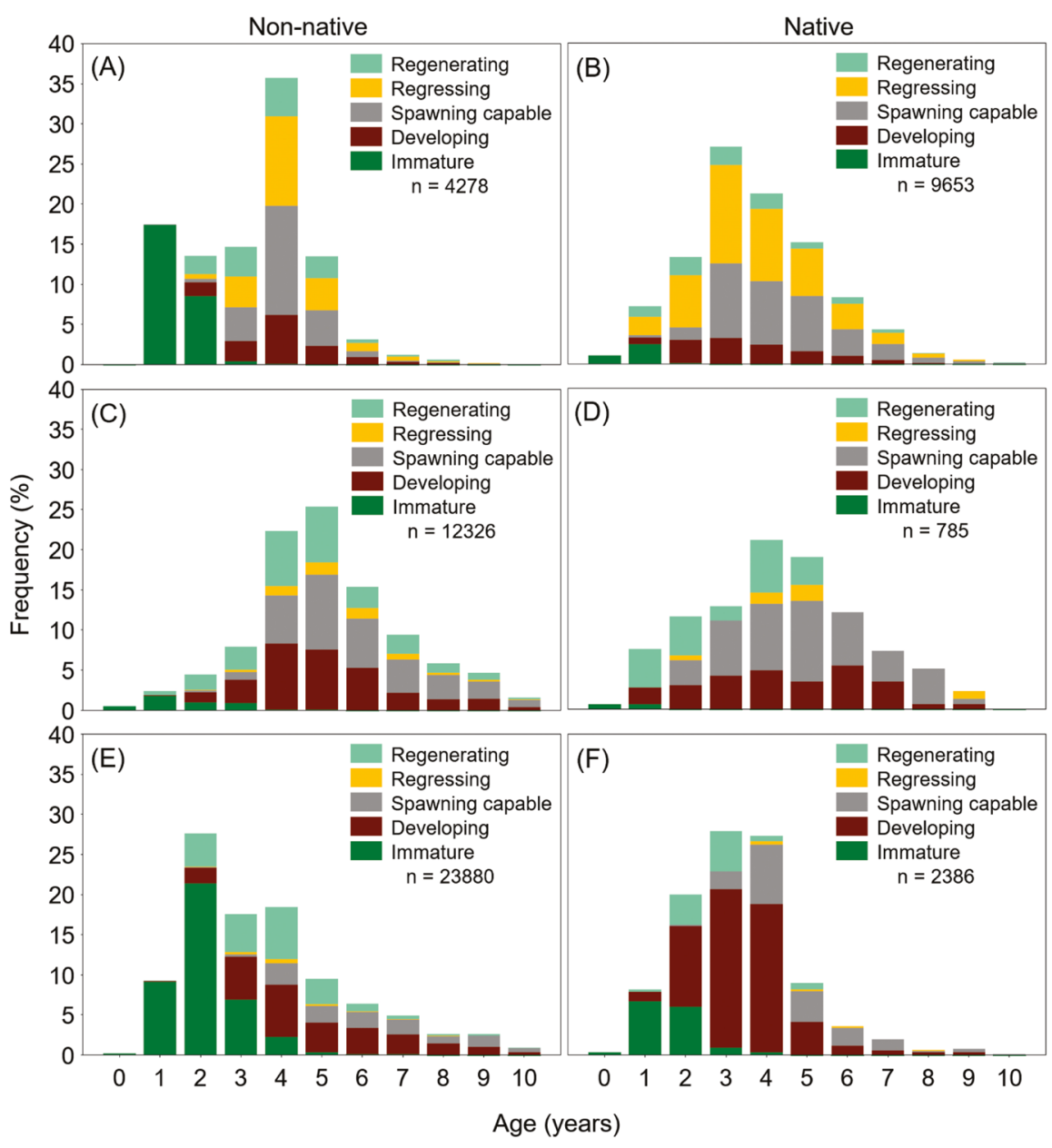

FIGURE 6 I Stages of gonadal maturation at each age class for individuals of Serrasalmus marginatus (non-native; left) and S. maculatus (native; right) piranha species in the upper Paraná River floodplain, at each sampled time-period. The classification was based on Brown-Peterson et al. (2011). A. and B. 1986-1988: first time-period; C. and D. 2000-2002: second time-period; E. and F. 2010-2012: third timeperiod. CPUE values are fewer when compared to total CPUE values since individuals without standard length, sex and maturation stage were not considered in the estimation of age.

River floodplain, the remarkable decrease in abundance of the native species between the first and second time-periods were likely a result of the introduction of the nonnative, which may have led to competition between them due to their similar ecological requirements. In a recent study, Alves et al. (2017) found in their results that both species use different energy sources and do not compete for food resources. However, as there are not studies regarding the invasion of $S$. marginatus that compare data from before and after the invasion, the idea of trophic competition can't be excluded (e.g., there is no evidence demonstrating if the inferior competitor changed or not its diet to allow coexistence). But besides trophic competition, the other most probable alternative for competition between both piranhas is in relation to reproductive requirements.

Piranha species share the same habitat preference, reproducing preferably in lentic waters (Agostinho, 2003). This was also supported by our results, once the abundance 
TABLE 4 I Estimated mean ages at first maturity $\left(A_{50}\right) \pm 95 \%$ C.I. (confidence intervals; in parentheses) and mean standard lengths at first maturity $\left(\mathrm{L}_{50}\right) \pm 95 \%$ C.I. (derived from 10000 bootstrap samples) for Serrasalmus marginatus (non-native) and S. maculatus (native) from the upper Paraná River floodplain in each time-period. $\dagger$ It was not possible to calculate the C.I. due to the low number of immature individuals. $\ddagger$ It was not possible to estimate $A_{50}$ and $L_{50}$ due to the absence of immature individuals.

\begin{tabular}{|c|c|c|c|c|}
\hline & Time-period & Sex & $A_{50}(95 \%$ C.I. $)$ & $\mathrm{L}_{50}(95 \%$ C.I. $)$ \\
\hline \multirow{9}{*}{ 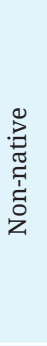 } & \multirow{3}{*}{$1986-1988$} & Both & $2.14(2.07-2.21)$ & $9.30(9.14-9.45)$ \\
\hline & & Female & $2.15(2.02-2.25)$ & $9.42(9.20-9.63)$ \\
\hline & & Male & $2.11(2.02-2.21)$ & $9.16(8.93-9.39)$ \\
\hline & \multirow{3}{*}{$2000-2002$} & Both & $1.37(1.18-1.54)$ & $7.50(7.04-7.92)$ \\
\hline & & Female & $1.44(1.14-1.70)$ & $7.82(7.16-8.43)$ \\
\hline & & Male & $1.33(1.08-1.53)$ & $7.24(6.55-7.83)$ \\
\hline & \multirow{3}{*}{$2010-2012$} & Both & $2.77(2.73-2.82)$ & $10.71(10.62-10.80)$ \\
\hline & & Female & $3.05(2.98-3.12)$ & $11.31(11.17-11.44)$ \\
\hline & & Male & $2.52(2.46-2.57)$ & $10.17(10.07-10.27)$ \\
\hline \multirow{9}{*}{ 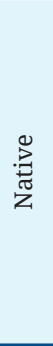 } & \multirow{3}{*}{$1986-1988$} & Both & $0.82(0.74-0.90)$ & 8.85 (8.67 - 9.02) \\
\hline & & Female & $0.98(0.96-1.00)$ & $9.13(8.96-9.30)$ \\
\hline & & Male & $0.66(0.52-0.80)$ & $8.62(8.28-8.90)$ \\
\hline & \multirow{3}{*}{$2000-2002$} & Both & $0.87 \dagger$ & $7.01(5.40-8.44)$ \\
\hline & & Female & $0.91 \dagger$ & $7.49(5.99-9.23)$ \\
\hline & & Male & t & $\ddagger$ \\
\hline & \multirow{3}{*}{$2010-2012$} & Both & $1.60(1.44-1.73)$ & $10.80(10.39-11.20)$ \\
\hline & & Female & $2.02(1.87-2.17)$ & $11.99(11.59-12.33)$ \\
\hline & & Male & $1.00(0.36-1.25)$ & $9.12(8.10-9.70)$ \\
\hline
\end{tabular}

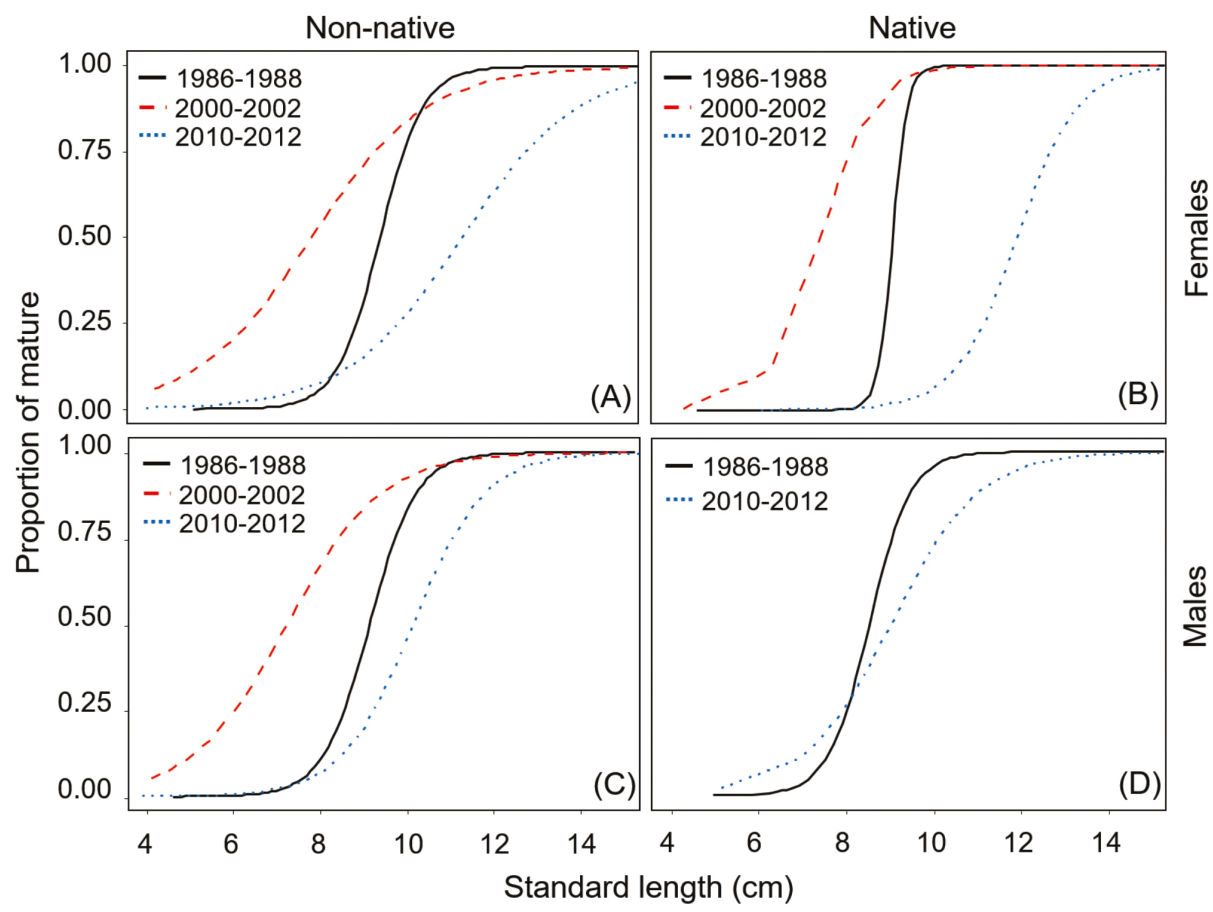

FIGURE 7 I Estimated mean lengths at first maturity $\left(\mathrm{L}_{50}\right)$ for both Serrasalmus marginatus (A and C, non-native) and $S$. maculatus (B and $\mathbf{D}$, native) piranha species for each sex and each sampled timeperiod in the upper Paraná River floodplain (continuous black line: 1986-1988, first time-period; dashed red line: 2000-2002, second time-period; dotted blue line: 2010-2012, third time-period). 
of species varied significantly in the habitats of the floodplain. In relation to this, we can highlight two factors that may have favored the establishment of the non-native species and disfavored the population of the native species: first, according to Agostinho (2003), the non-native species also reproduces in lotic habitats, acquiring reproductive advantage over the native species (more available spawning grounds for the nonnative). Second, the absence of flood pulses in the upper Paraná River in 1986 and 1987 may have affected the native species population by decreasing the availability of spawning grounds for it, since it only reproduces in lentic habitats and the connectivity to these habitats may have been harmed due to lower water levels (Agostinho et al., 1997). In the second scenario, we believe that the environmental condition was crucial for the behavior of the population of both species in the following years, once it may have severely affected the number of individuals of the native species in the following generations.

Despite the considerable difference in abundances between both species after the first time-period, both populations showed similar characteristics in the second timeperiod: higher frequency of older individuals and lower values of mean age and length at first maturity (coupled with a higher proportion of mature individuals). According to Rodrigues et al. (2018), studying the same time scale analyzed here, both piranhas shared the same habitats (spatially aggregated) in first and second time-periods, resulted from the high and rapid spread of the non-native species in the floodplain. This cooccurrence pattern (individuals of both species at the same site) might have resulted in unavoidable competition because the abundance of the non-native species was increased. In this sense, a higher frequency of older individuals in the second period could indicate a longer reproductive lifespan. Reznick et al. (2006) found in their study that guppies species that evolved with predators and under high mortality have matured at earlier ages, presenting longer lifespans. This longer lifespan refers to a longer reproductive lifespan, which is the component of the life history that can make a direct contribution to individuals fitness (Reznick et al., 2006). Therefore, when confronting an environment with stressful conditions (e.g., a possible competition), both piranhas species could have developed physiological responses that would reflect in longer reproductive lifespan, resulting in increased fitness and population.

In relation to the mortality rates, the non-native species did not show an advantage over the native species, since its mortality rates were not always lower than the native one. For both piranhas, the decrease in mortality rate in the second time-period may be particularly related to the persistence of older individuals in the population. Thus, with higher frequency of older individuals, mortality decreased, since this estimate is based only on individuals that are totally recruited in the population (Ricker, 1975). However, the increase in the mortality rate for the native species in the last time-period resembles the mortality observed in the first time-period, as well as the age structure. Unfortunately, the total mortality rate for $S$. maculatus in the upper Paraná River floodplain was not previously estimated, limiting comparisons. We expect, however, that the native species may be recovering its population at this floodplain after the temporal confrontation following the massive entrance of the non-native species. This situation was suggested by Agostinho, Júlio Jr. (2002) and observed by Rodrigues et al. (2018), reinforcing that both species may continue to coexist at the floodplain, but with the native one in much lower abundances than the non-native species. 
Furthermore, the decrease in age and length at first maturity for both piranhas in the second time-period is probably an additional evidence of physiological strategies that species developed in response to stressful conditions reflecting in improved reproduction effort. Early-life reproductions favor the success of species by increasing population size and colonization rate, and decreasing the temporal life-cycle (RamírezGarcía et al., 2018). These triggered physiological responses may have guaranteed recruitment and survival for both native and non-native species in the face of local and regional competition, as it was suggested by Gomiero et al. (2009) for Cichla kelberi Kullander \& Ferreira, 2006 in invaded environments. The physiological responses ensured the population increase for the two piranhas, as clearly noticed in the third time-period. However, the abundance of immature individuals of non-native species was substantially higher than that of the native species, which could contribute to its population growth and geographic range expansion. This could be a reflection of the longer reproductive period with continuous releases of oocytes by S. marginatus (guaranteeing more descendants; Melo et al., 2017) and its higher reproductive activity in lotic environments stated by Agostinho (2003), as already mentioned above. Additionally, the abundance of immature individuals of the native species, in the third time-period, was similar to that observed in the first time-period, even at smaller size populations. This evidence indicates a better reproductive performance of the species in this period.

Therefore, more than using linear models to make a broad generalization about which factors had significant influences on the abundance of species, our study innovates by comparing over a long time series variations in population and reproductive attributes of congeneric species and suggesting, even with detailed limitations throughout the text, a likely ecological mechanism after a period of invasion. Both piranha species developed physiological responses over the years in front of stressful conditions during their cooccurrence in the upper Paraná River floodplain, reflecting in their population and reproductive attributes. Besides the substantial decrease in abundance of the native species and the increase of the non-native species, both populations had considerable variations in their parameters towards increase in the population, especially the native species ( $S$. maculatus), suggesting direct effects of stressful conditions on growth, mortality, and size-structure of population. Thus, we believe that these shifts and physiological responses in population attributes for both species prevented competitive exclusion and are still allowing their coexistence in the upper Paraná River floodplain.

\section{ACKNOWLEDGMENTS}

The authors would like to thank the Núcleo de Pesquisas em Limnologia, Ictiologia e Aquicultura (Nupélia) of the Universidade Estadual de Maringá (UEM) for providing the sampling and logistical support; projects Pesquisas Ecológicas de Longa Duração (PELD) and Programa de Apoio ao Desenvolvimento Científico e Tecnológico e Ciências Ambientais (PADCT/CIAMB) for delivering the data. The authors would also like to thank the Conselho Nacional de Desenvolvimento Científico e Tecnológico (CNPq) and Coordenação de Aperfeiçoamento de Pessoal de Nível Superior (CAPES) 
for having granted the scholarship to Amanda C. Rodrigues, Natália C. L. dos Santos and Matheus T. Baumgartner, as well as Herick S. Santana for remarkable improvements to the earliest version of this manuscript.

\section{REFERENCES}

- Agostinho CS. Reproductive aspects of piranhas Serrasalmus spilopleura and Serrasalmus marginatus into the upper Paraná River, Brazil. Braz J Biol. 2003; 63(1):1-6. https://doi.org/10.1590/S151969842003000100002

- Agostinho CS, Júlio Jr. HF. Observation of an invasion of the piranha Serrasalmus marginatus Valenciennes, 1847 (Osteichthys, Serrasalmidae) into the Upper Paraná River, Brazil. Acta Sci. 2002; 24(2):391-95.

- Agostinho CS, Marques EE. Idade e crescimento das piranhas Serrasalmus spilopleura e Serrasalmus marginatus (Osteichthyes, Serrasalminae) do alto rio Paraná. Revista UNIMAR. 1994; 16(Suppl. 3):175-87.

- Agostinho AA, Zalewski M. A planície alagável do alto rio Paraná: importância e preservação. Maringá: EDUEM; 1996.

- Agostinho CS, Hahn NS, Marques EE. Patterns of food resource use by two congeneric species of piranhas (Serrasalmus) on the upper Paraná River floodplain. Braz J Biol. 2003; 63(2):177-82. https://doi.org/10.1590/S151969842003000200002

- Agostinho AA, Júlio Jr. HF, Gomes LC, Bini LM, Agostinho CS. Composição, abundância e distribuição espaçotemporal da ictiofauna. In: Vazzoler AEAM, Agostinho AA, Hahn NS, editors. A planície de inundação do alto rio Paraná: aspectos físicos, biológicos e socioeconômicos. Maringá: EDUEM; 1997. p.179-208.

- Agostinho AA, Pelicice FM, Gomes LC. Dams and the fish fauna of the Neotropical region: impacts and management related to diversity and fisheries. Braz J Biol. 2008; 68(4):1119-32. https://doi.org/10.1590/ s1519-69842008000500019

- Agostinho AA, Suzuki HI, Fugi R, Alves DC, Tonella LH, Espindola LA. Ecological and life history traits of Hemiodus orthonops in the invasion process: looking for clues at home. Hydrobiologia. 2015; 746(1):415-30. https://doi.org/10.1007/ s10750-014-2030-2
- Alexandre PC, Luiz EA, Piana PA, Gomes LC, Agostinho AA. Relação estoque-recrutamento para as piranhas Serrasalmus marginatus (Valenciennes, 1847) e S. maculatus (Kner, 1860) no rio Baía, alto rio Paraná. Acta Sci Biol Sci. 2004; 26(3):303-07. https://doi.org/10.4025/ actascibiolsci.v26i3.1544

- Alves GHZ, Figueiredo BRS, Manetta GI, Sacramento PA, Tófoli RM, Benedito E. Trophic segregation underlies the coexistence of two piranha species after the removal of a geographic barrier. Hydrobiologia. 2017; 797(1):57-68. https:// doi.org/10.1007/s10750-017-3159-6

- Bøhn T, Amundsen P, Sparrow A. Competitive exclusion after invasion? Biol Invasions. 2008; 10(3):359-68. https://doi. org/10.1007/s10530-007-9135-8

- Brown-Peterson NJ, Wyanski DM, Saborido-Rey F, Macewicz BJ, LowerreBarbieri SK. A Standardized terminology for describing reproductive development in fishes. Mar Coast Fish. 2011; 3(1):52-70. https://doi.org/10.1080/19425120.2011.55 5724

- Cucherousset J, Olden JD. Ecological impacts of non-native freshwater fishes. Fisheries. 2011; 36(5):215-30. https://doi.or g/10.1080/03632415.2011.574578

- Ellender BR, Weyl OLF, Swartz ER. Invasion of a headwater stream by nonnative fishes in the Swartkops River system, South Africa. Afr Zool. 2011; 46(1):39-46. https://doi.org/10.1080/156270 20.2011.11407477

- Gois KS, Pelicice FM, Gomes LC, Agostinho AA. Invasion of an Amazonian cichlid in the Upper Paraná River: facilitation by dams and decline of a phylogenetically related species. Hydrobiologia. 2015; 746(1):401-13. https:// doi.org/10.1007/s10750-014-2061-8 
- Gomiero LM, Carmassi AL, Rondineli GR, Villares Junior GA, Braga FMS. Growth and mortality of Cichla spp. (Perciformes, Cichlidae) introduced in Volta Grande Reservoir (Grande River) and in a small artificial lake in Southeastern Brazil. Braz J Biol. 2010; 70(4):1093-101. https://doi.org/10.1590/ S1519-69842010000500027

- Gomiero LM, Villares Junior GA, Naous F. Reproduction of Cichla kelberi Kullander and Ferreira, 2006 introduced into an artificial lake in southeastern Brazil. Braz J Biol. 2009; 69(1):175-83. https://doi. org/10.1590/S1519-69842009000100023

- Gulland JA. Manual of methods for fish stock assessment - Part 1: Fish Population Analysis. Rome: FAO; 1969.

- Hardin G. The competitive exclusion principle. Science. 1960; 131(3409):1292-97. https://doi.org/10.1126/ science.131.3409.1292

- Jégu M, dos Santos GM. Mise au point à propos de Serrasalmus spilopleura Kner, 1858 et réhabilitation de $S$. maculatus Kner, 1858 (Characidae: Serrasalminae). Cybium. 2001; 25(2):119-43.

- Jermacz Ł, Kobak J, Dzierżyńska A, Kakareko T. The effect of flow on the competition between the alien racer goby and native European bullhead. Ecol Freshw Fish. 2015; 24(3):467-77. https://doi. org/10.1111/eff.12162

- Júlio Junior HF, Dei Tós C, Agostinho AA, Pavanelli CS. A massive invasion of fish species after eliminating a natural barrier in the upper Paraná River basin. Neotrop Ichthyol. 2009; 7(4):709-18. https://doi. org/10.1590/S1679-62252009000400021

- Jůza T, Blabolil P, Baran R, Bartoň D, Čech M, Draštík V et al. Collapse of the native ruffe (Gymnocephalus cernua) population in the Biesbosch lakes (the Netherlands) owing to round goby (Neogobius melanostomus) invasion. Biol Invasions. 2018; 20(6):1523-35. https://doi. org/10.1007/s10530-017-1644-5

- MacNeil C, Prenter J, Briffa M, Fielding NJ, Dick JTA, Riddell GE et al. The replacement of a native freshwater amphipod by an invader: roles for environmental degradation and intraguild predation. Can J Fish Aquat Sci. 2004; 61(9):1627-35. https://doi.org/10.1139/F04091
- Melo GSR, Santana HS, Dei Tos C. Ovarian histology and fecundity in the evaluation of the reproduction of the invasive species Serrasalmus marginatus (Characidae) on a neotropical floodplain. Acta Sci Biol Sci. 2017; 39(3):339-47. https:// doi.org/10.4025/actascibiolsci.v39i3.33021

- Miranda LE, Bettoli PW. Mortality. In: Guy CS, Brown ML, editors. Analysis and interpretation of freshwater fisheries data. Maryland: American Fisheries Society; 2007. p.229-77.

- Ogle DH. FSA: Fisheries Stock Analysis. R package version 0.8.17 [Internet]. 2017. Available from: https://github.com/ droglenc/FSA

- Ortega JCG, Agostinho AA, Santos NCL, Agostinho KDGL, Oda FH, Severi W, Bini LM. Similarities in correlates of native and introduced fish species richness distribution in Brazilian reservoirs. Hydrobiologia. 2018; 817(1):167-77. https:// doi.org/10.1007/s10750-018-3508-0

- R Development Core Team. R: A language and environment for statistical computing. Vienna: R Foundation for Statistical Computing; 2017.

- Ramírez-García A, Ramírez-Herrejón JP, Medina-Nava M, Hernández-Morales R, Domínguez-Domínguez 0 . Reproductive biology of the invasive species Pseudoxiphophorus bimaculatus and Poecilia sphenops in the Teuchitlán River, México. J Appl Ichthyol. 2018; 34(1):81-90. https://doi.org/10.1111/jai.13543

- Reznick D, Bryant M, Holmes D. The evolution of senescence and postreproductive lifespan in guppies (Poecilia reticulata). Plos Biol. 2006; 4(1):e7. https:// doi.org/10.1371/journal.pbio.0040007

- Ricker WE. Estimation of survival rate and mortality rate from age composition. In: Ricker WE. Computation and interpretation of biological statistics of fish population. Ottawa: Department of the Environment Fisheries and Marine Service; 1975. p.29-74.

- Rodrigues AC, Santana HS, Baumgartner MT, Gomes LC. Coexistence between native and nonnative species: the invasion process and adjustments in distribution through time for congeneric piranhas in a Neotropical floodplain. Hydrobiologia. 2018; 817(1):279-91. https://doi.org/10.1007/ s10750-018-3541-z 
- Ross ST. Mechanisms structuring stream fish assemblages: are there lessons from introduced species? Environ Biol Fish. 1991; 30(4):359-68. https://doi.org/10.1007/ BF02027979

- Saylor RK, Lapointe NWR, Angermeier PL. Diet of non-native northern snakehead (Channa argus) compared to three cooccurring predators in the lower Potomac River, USA. Ecol Freshw Fish. 2012; 21(3):443-52. https://doi.org/10.1111/j.16000633.2012.00563.x

- Shelton JM, Day JA, Griffiths CL. Influence of largemouth bass, Micropterus salmoides, on abundance and habitat selection of Cape galaxias, Galaxias zebratus, in a mountain stream in the Cape Floristic Region, South Africa. Afr J Aquat Sci. 2008; 33(3):201-10. https://doi. org/10.2989/AJAS.2008.33.3.2.614
- Sparre P, Venema SC. Introduction to tropical fish stock assessment. Part 1: Manual. Rome: FAO Fisheries Technical Paper; 1992.

- Vitule JRS, Skóra F, Abilhoa V. Homogenization of freshwater fish faunas after the elimination of a natural barrier by a dam in Neotropics. Divers Distrib. 2012; 18(2):111-20. https://doi.org/10.1111/ j.1472-4642.2011.00821.x

- Yates P, Ziegler P, Welsford D, McIvor J, Farmer B, Woodcock E. Spatio-temporal dynamics in maturation and spawning of Patagonian toothfish Dissostichus eleginoides on the sub-Antarctic Kerguelen Plateau. J Fish Biol. 2018; 92(1):34-54. https://doi.org/10.1111/jfb.13479

\section{Neotropical |chthyology}

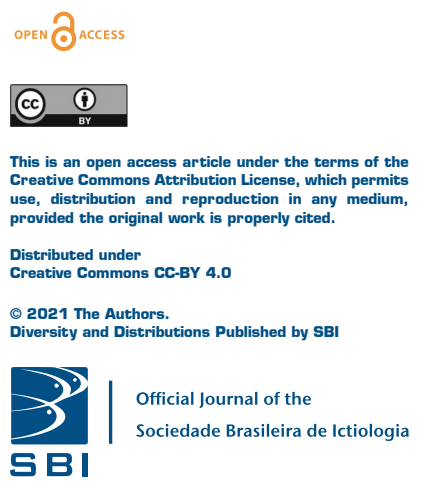

\section{AUTHOR'S CONTRIBUTION}

Amanda Cantarute Rodrigues: Conceptualization, Data curation, Formal analysis, Investigation, Methodology, Writing-original draft.

Natália Carneiro Lacerda dos Santos: Conceptualization, Formal analysis, Methodology, Writingoriginal draft, Writing-review and editing.

Matheus Tenório Baumgartner: Conceptualization, Formal analysis, Methodology, Writing-original draft, Writing-review and editing.

Luiz Carlos Gomes: Conceptualization, Data curation, Formal analysis, Funding acquisition, Methodology, Supervision, Writing-original draft, Writing-review and editing.

\section{ETHICAL STATEMENT}

Approved by the Animal Use Ethics Committee of the Universidade Estadual de Maringá (CEUA/UEM), protocol CEUA n ${ }^{\circ} 1420221018$ (ID 001974).

\section{COMPETING INTERESTS}

The authors declare no competing interests.

\section{HOW TO CITE THIS ARTICLE}

- Rodrigues AC, Santos NCL, Baumgartner MT, Gomes LC. Adjustments in population and reproductive dynamics of native and non-native congeneric species during 26 years after invasion. Neotrop Ichthyol. 2021; 19(1):e200033. https://doi.org/10.1590/1982-0224-2020-0033 